\title{
Evaluation of Chemical Defense and Chemical Diversity in the Exotic Bryozoan Amathia verticillata
}

\author{
Larissa A. H. dos Santos, ${ }^{a}$ Etiene E. G. Clavico, ${ }^{a}$ Lizbeth L. L. Parra,${ }^{b}$ Roberto G. S. \\ Berlinck, ${ }^{*, b}$ Antonio G. Ferreira, ${ }^{c}$ Valerie J. Paul ${ }^{d}$ and Renato C. Pereira ${ }^{*, a}$ \\ ${ }^{a}$ Departamento de Biologia Marinha, Instituto de Biologia, Universidade Federal Fluminense, \\ CP 100.644, 24001-970 Niterói-RJ, Brazil \\ ${ }^{b}$ Instituto de Química de São Carlos, Universidade de São Paulo, CP 780, \\ 13560-970 São Carlos-SP, Brazil
}

'Departamento de Química, Universidade Federal de São Carlos, 13565-905 São Carlos-SP, Brazil

${ }^{d}$ Smithsonian Marine Station at Fort Pierce, 701 Seaway Drive, FL34949, USA

\begin{abstract}
The present investigation tests the effects against feeding by fishes of crude extracts obtained from eleven distinct populations of the bryozoan Amathia verticillata, an invasive species found globally in tropical to warm-temperate waters. Investigation of extracts from 11 populations of A. verticillata led to the identification and quantification of the known indole alkaloid 2,5,6-tribromo- $N$-methylgramine and isolation and identification of the new indole alkaloid, 2,6-dibromo- $N$-methylgramine. One extract of $A$. verticillata from Brazil significantly deterred feeding, while other extracts of $A$. verticillata from Florida significantly stimulated feeding by fishes, in field assays performed in Brazil. The same extracts of Florida samples showed variable effects on feeding, ranging from attraction to deterrence, in assays carried out in Florida. The absence of broad chemical defenses against feeding by fish suggests that the establishment of A. verticillata as an invasive species into new areas may be due to reasons other than defensive chemistry.
\end{abstract}

Keywords: Amathia verticillata, chemical defense, exotic bryozoan, alkaloid

\section{Introduction}

Bryozoans are sessile, colonial invertebrates formed by a number of genetically identical, physiologically interconnected nodules called zooids that reproduce through asexual budding. Bryozoans are considered to be metaorganisms, hosting whole communities of microorganisms and small invertebrates within their colonial structures. ${ }^{1,2}$ Variation in modes of budding lead to bryozoan species which vary greatly morphologically as encrusting and erect growth forms. ${ }^{3}$

Several species of bryozoans are known as sources of bioactive natural products; however, secondary metabolites from bryozoans have been limited in number compared to other marine invertebrates. ${ }^{4,5}$ For example, only one compound was reported from bryozoans in 2015. ${ }^{6}$ Possible reasons for the limited investigation of bryozoan natural products are because these animals are

*e-mail: rcrespo@id.uff.br; rgsberlinck@iqsc.usp.br difficult to collect in large amounts due to their encrusting growth form, seasonal occurrence and small size, besides the taxonomy of the group is rather obscure and difficult. Secondary metabolites from bryozoans include the potent anticancer bryostatins ${ }^{7}$ as well as alkaloids and other heteroatom-containing compounds. ${ }^{4,8}$ Natural products from bryozoans have been of interest due to uniqueness of their structures and their biological and ecological activities. $^{9}$

Ecological roles of secondary metabolites from bryozoans have been demonstrated on several occasions. Crude extracts from the bryozoans Amathia wilsoni and Orthoscuticella ventricosa acted as chemical defenses against feeding by the fish Acanthaluteres sp., ${ }^{10}$ and also exhibited strong anti-bacterial activity. ${ }^{11}$ Larvae of Bugula neritina are chemically defended against predators by bryostatins. ${ }^{12}$ As has been observed for other sessile invertebrates, bryozoan secondary metabolites can be transferred up the food chain. The carnivorous nudibranch Roboastra tigris preys upon 
two other nudibranchs, Tambja abdere and T. eliora, that prey upon the bryozoan Sessibugula translucens. These nudibranch species accumulate feeding inhibitory secondary metabolites derived from the bryozoans. ${ }^{13}$ Other nudibranch species, Tambja stegosauriformis and Okenia zoobotryon, prey upon the bryozoans Bugula dentata, and Amathia verticillata (previously $Z$. verticillatum) ${ }^{14}$ respectively, and sequester compounds from these preys. ${ }^{15} \mathrm{~A}$ tripeptide found in the invasive bryozoan species Bugula flabellata ${ }^{16}$ has been previously isolated from the nudibranch Janolus cristatus. ${ }^{17}$

Amathia verticillata is an erect, soft-bodied bryozoan that produces or accumulates brominated indole alkaloids such as 2,5,6-tribromo- $N$-methylgramine (1). This compound acts as an antifouling agent, inhibiting larval settlement of the barnacle Balanus amphitrite and settlement of the blue mussel Mytilus edulis. ${ }^{18}$ Previous studies revealed the presence of brominated indole alkaloids, specifically 2,5,6-tribromo- $N$-methylgramine, in A. verticillata specimens from California (USA), ${ }^{19}$ Shimizu (Japan) ${ }^{18}$ and Rio de Janeiro (Brazil). ${ }^{15}$ This alkaloid was isolated from the nudibranch Okenia zoobotryon and from its prey, the bryozoan A. verticillata $\left(=\right.$ Zoobotryon verticillatum).${ }^{15}$ In addition to 2,5,6-tribromo- $\mathrm{N}$-methylgramine, the biosynthetically related 2,5,6-tribromo- $N$-methylindole-3-carbaldehyde was identified in colonies from Spain. ${ }^{20}$

Defensive chemicals in exotic marine species may promote or facilitate an invasion in marine environments. For example, the chemically defended green seaweed Caulerpa taxifolia invaded several areas of the Mediterranean, which may have been facilitated by the feeding deterrent activity of the sesquiterpene caulerpenyne. ${ }^{21}$ Defensive chemicals against fish predation and competitors were suggested as a facilitator for the perpetuation and expansion of the exotic coral Stereonephthya aff. curvata in a southeastern Brazilian region. ${ }^{22}$ It has been proposed that defensive chemicals can be used to predict the potential invasiveness of introduced species. ${ }^{22}$ The origin of $A$. verticillata is not known, but it is considered as an invasive species in many places around the world, ${ }^{23,24}$ such as in Australia and New Zealand, ${ }^{25}$ Brazil ${ }^{26}$ Portugal, ${ }^{27}$ and in the United States ${ }^{28}$ among others. It is listed as an invasive species least desired by the United States Early Detection Program. ${ }^{29}$

In the present study we investigated the chemical profiles of the exotic A. verticillata collected in different locations (Brazil, United States and Italy). Additionally, we also aimed to investigate if the extracts of $A$. verticillata act as chemical defenses against feeding by natural communities of fishes.

\section{Experimental}

\section{Collection site}

Samples of Amathia verticillata were collected at different sites along the Brazilian coastline (Table 1), located at the States of Santa Catarina (Porto Belo), São Paulo (São Vicente and São Sebastião), Rio de Janeiro (Cabo Frio and Arraial do Cabo), Bahia (Salvador), and Rio Grande do Norte (Natal). Samples of A. verticillata were also obtained in Italy (La Spezia) and in the Indian River Lagoon in Florida, USA, at Coon Island, Little Jim, Jupiter and Peacock's Pocket (Table 1). Unlike some bryozoans, $A$. verticillata is a conspicuous and well known species of bryozoan that is readily recognized in the field. ${ }^{14}$ Identification of $A$. verticillata specimens was further confirmed using DNA sequencing analysis (data not yet published).

Upon collection, samples were placed in containers with seawater and transported to the laboratory immediately. The excess of water was eliminated using a salad spinner. The wet weight ( $\mathrm{mg}$ ) of the animal was taken and its volume (in $\mathrm{mL}$ ) was measured using water displacement in a graduated cylinder. These data were recorded prior to the animal extraction and used to obtain the natural concentration of extracts for preparation of foods for feeding assays.

\section{Amathia verticillata extraction and chemical analysis}

Isolation of metabolites from A. verticillata samples was performed as previously described ${ }^{15}$ Briefly, colonies of each A. verticillata sample were extracted with $\mathrm{MeOH}$ in an ultrasound bath for 2 minutes, and further extracted for one hour. This procedure was repeated two times. The concentrated $\mathrm{MeOH}$ extract of each A. verticillata sample was defatted by liquid-liquid partition with hexane $(4 \times 50 \mathrm{~mL})$. After evaporation to dryness, a $1 \mathrm{mg}$ aliquot of the $\mathrm{MeOH}$ fraction of each A. verticillata sample was analyzed by high-performance liquid chromatographyultraviolet-mass spectrometry (HPLC-UV-MS). The conditions of analysis were the following: Waters X-Terra MS $\mathrm{C}_{18}$ column $(3.5 \mu \mathrm{m}, 2.1 \times 50 \mathrm{~mm})$, a gradient of $\mathrm{MeOH}$ in $\mathrm{H}_{2} \mathrm{O}$ (starting at $\mathrm{MeOH} / \mathrm{H}_{2} \mathrm{O}$ 2:8 until $100 \%$ $\mathrm{MeOH}$ for 20 minutes, linear curve), with a flow rate of $0.5 \mathrm{~mL} \mathrm{~min}^{-1}$. The UV detection was performed using a photodiode array detector scanning from 200 to $400 \mathrm{~nm}$. Mass spectrometry detection was in positive electrospray mode, with a cone voltage of $25 \mathrm{~V}$. Quantitative analyses were conducted to assess the amounts of the major and known metabolite 2,5,6-tribromo- $N$-methylgramine $1 .{ }^{15,18,19}$ The minor metabolite 2,6-dibromo- $N$-methylgramine 2 
Table 1. Occurrence, voucher numbers (CEBIMar-USP collection), a amounts of 2,5,6-tribromo- $N$-methylgramine (1) and 2,6-dibromo- $N$-methylgramine (2) in samples of A. verticillata. Amounts of $\mathbf{2}$ were not determined

\begin{tabular}{|c|c|c|c|c|c|c|}
\hline Place & State & Voucher & Coordinates & Country & $\begin{array}{c}\text { Concentration of } \mathbf{1} / \\
\left(\mathrm{mg} \mathrm{g}^{-1}\right)\end{array}$ & Presence of $\mathbf{2}$ \\
\hline Porto Belo & Santa Catarina & Z144 & $\begin{array}{c}27^{\circ} 09^{\prime} 13.76^{\prime \prime} \mathrm{S} \\
48^{\circ} 32^{\prime} 41.89^{\prime \prime} \mathrm{W}\end{array}$ & Brazil & 0.589 & $X$ \\
\hline São Vicente & São Paulo & Z64 & $\begin{array}{l}23^{\circ} 58^{\prime} 26.39^{\prime \prime} \mathrm{S} \\
46^{\circ} 23^{\prime} 6.51^{\prime \prime} \mathrm{W}\end{array}$ & Brazil & 0.051 & \\
\hline Araçá & São Paulo & $\mathrm{Z} 12$ & $\begin{array}{c}23^{\circ} 48^{\prime} 54.72^{\prime \prime} \mathrm{S} \\
45^{\circ} 24^{\prime} 22.44^{\prime \prime} \mathrm{W}\end{array}$ & Brazil & 0.055 & \\
\hline Cabo Frio & Rio de Janeiro & $\mathrm{Z} 100$ & $\begin{array}{l}22^{\circ} 52^{\prime} 32.20 \text { '’ } \\
42^{\circ} 01^{\prime} 30.57^{\prime \prime} \mathrm{W}\end{array}$ & Brazil & 0.683 & $\mathrm{X}$ \\
\hline Arraial do Cabo & Rio de Janeiro & Z101 & $\begin{array}{l}22^{\circ} 58^{\prime} 13.04 " \mathrm{~S} \\
42^{\circ} 01^{\prime} 04.69^{\prime \prime} \mathrm{W}\end{array}$ & Brazil & 2.480 & \\
\hline Salvador & Bahia & Z175 & $\begin{array}{c}12^{\circ} 54^{\prime} 50.03^{\prime \prime} \mathrm{S} \\
38^{\circ} 29^{\prime} 30.28^{\prime \prime} \mathrm{W}\end{array}$ & Brazil & 0.367 & \\
\hline Natal & Rio Grande do Norte & Z134 & $\begin{array}{c}5^{\circ} 45^{\prime} 13.87 \text { 'S } \\
35^{\circ} 12^{\prime} 10.91 \text { 'W }\end{array}$ & Brazil & 0.024 & \\
\hline Coon Island & Florida & Z211 & $\begin{array}{l}27^{\circ} 28^{\prime} 19.93^{\prime \prime} \mathrm{N} \\
80^{\circ} 18^{\prime} 06.70^{\prime \prime} \mathrm{W}\end{array}$ & USA & 0.201 & $\mathrm{X}$ \\
\hline Little Jim & Florida & Z209 & $\begin{array}{l}27^{\circ} 28^{\prime} 37.16^{\prime \prime} \mathrm{N} \\
80^{\circ} 18^{\prime} 40.23^{\prime \prime} \mathrm{W}\end{array}$ & USA & 0.045 & $\mathrm{X}$ \\
\hline Peacock's Pocket & Florida & Z207 & $\begin{array}{l}28^{\circ} 35^{\prime} 47.64^{\prime \prime} \mathrm{N} \\
80^{\circ} 43^{\prime} 49.07^{\prime \prime} \mathrm{W}\end{array}$ & USA & 0.316 & \\
\hline La Spezia & Liguria & Z202 & $\begin{array}{c}44^{\circ} 05^{\prime} 59.11^{\prime \prime} \mathrm{N} \\
9^{\circ} 49^{\prime} 43.02{ }^{\prime \prime} \mathrm{E}\end{array}$ & Italy & 0.571 & \\
\hline
\end{tabular}

aCEBIMar: Centro de Biologia Marinha; USP: Universidade de São Paulo.

could be detected but not quantified because it was present in very small amounts. ${ }^{1} \mathrm{H}$ and ${ }^{13} \mathrm{C}$ NMR analyses were performed on a Bruker AV-600 spectrometer (14.7 Tesla), at $600 \mathrm{MHz}$ for ${ }^{1} \mathrm{H}$ and $150 \mathrm{MHz}$ for ${ }^{13} \mathrm{C}$ detection. Spectra were obtained in either DMSO- $d_{6}$ or $\mathrm{MeOH}-d_{4}$, referenced to the tetramethylsilane signal, at $25^{\circ} \mathrm{C}$.

Isolation of 2,6-dibromo- $N$-methylgramine (2)

Specimens of A. verticillata $(8.3 \mathrm{~g})$ preserved in EtOH were separated from the solvent and exhaustively extracted with $\mathrm{MeOH}$. The $\mathrm{EtOH}$ and $\mathrm{MeOH}$ extracts were pooled, concentrated to $50 \mathrm{~mL}$ and deffated with hexanes $(4 \times 50 \mathrm{~mL})$ in order to remove fatty acids, sterols and other nonpolar constituents. The polar $\mathrm{MeOH}$ fraction $(157 \mathrm{mg}$ ) was separated using a Waters X-Terra column $(50 \times 2.1 \mathrm{~mm}, 3.5 \mu \mathrm{m})$, with a gradient of $\mathrm{MeOH}$ in $\mathrm{H}_{2} \mathrm{O}$, from $20: 80 \mathrm{MeOH} / \mathrm{H}_{2} \mathrm{O}$ to $100 \% \mathrm{MeOH}$ during $30 \mathrm{~min}$, at $0.5 \mathrm{~mL} \mathrm{~min}^{-1}$ flow rate. An amount of $0.8 \mathrm{mg}$ of compound 2 was obtained.

\section{Field feeding bioassays with fishes}

The total organic crude extract of A. verticillata was filtered and the solvent was evaporated in vacuo to dryness.
The extract was incorporated into food pieces (see details below) at a natural concentration found in A. verticillata colonies, calculated by dividing the dried extract weight by the animal volume as previously described.

Commercial fish food (Alcon Ltda) was used to make the artificial food for the assays aiming to evaluate the action of defensive chemicals. Since no information on A. verticillata protein concentration was found in the literature, we used artificial food that presented nutritional value similar (about $25 \mathrm{mg}$ of protein $\mathrm{mL}^{-1}$ ) to that found in the bryozoan Bugula neritina. ${ }^{30}$

Artificial food pellets were prepared by mixing $0.5 \mathrm{~g}$ of carrageenan powder, $0.5 \mathrm{~g}$ of commercial fish food and seawater, yielding a final volume of $10 \mathrm{~mL}$. Foods were prepared: (i) without extract (control), and (ii) with extract (treatment). The mixture to prepare the treatment food (carrageenan + fish food + seawater + crude extract dissolved in $1 \mathrm{~mL}$ of $\mathrm{MeOH}$ ) was vigorously stirred in a hot plate until it melted and added into acrylic molds $(5.0 \times 0.4 \times 5.0 \mathrm{~cm})$ containing cotton strings for later attachment of the artificial foods to substrate (bottom) during the bioassays. Control food was prepared following the same protocol but replacing the crude extract by $1 \mathrm{~mL}$ of $\mathrm{MeOH}$ in order to control for any possible effect of solvent used in treatment food. The artificial food matrix 
was removed from the mold and cut in ten small pieces of identical size $(1.0 \times 0.4 \times 2.5 \mathrm{~cm})$. Control and treatment food pieces were individually tagged and each pair was attached to a transparent nylon line (fishing line), which was attached to small rocks placed at the bottom of the sea floor.

For each population of $A$. verticillata, ten replicate lines, each line containing a control and treatment food piece, were randomly attached to the sea bottom, in order to be exposed to generalist feeding fishes in the field. Each replicate was taken out of the water when at least $50 \%$ of the area of the artificial food was consumed so as to obtain a measurable consumption. Pairs for which both control and treatment pieces were equally consumed ( 0 or $100 \%)$ were excluded, since these replicates did not reveal any information of differential consumption. Area consumed (in $\mathrm{cm}^{2}$ ) was calculated using Image $\mathbf{J}$ software. The amount of consumption of control and treatment food pieces was evaluated by statistical paired $t$-test.

Field feeding assays aiming to evaluate feeding deterrence by $A$. verticillata extracts were performed at Jupiter, Florida (USA), and at Arraial do Cabo, Rio de Janeiro (Brazil). Florida assays were performed with extracts obtained from locally collected A. verticillata, at 4 distinct localities. In Rio de Janeiro the assays were performed with extracts of $A$. verticillata collected in 5 different places along the coastlines of Brazil, 4 in USA and 1 in Italy, aiming to compare the consumption of A. verticillata extracts from different locations.

\section{Results and Discussion}

2,5,6-Tribromo- $N$-methylgramine (1) was identified as the major secondary metabolite found in all samples of A. verticillata collected at seven different locations along the Brazilian coastline, three in Florida, USA, and one in Italy (Table 1). A wide variation in the concentration of compound $\mathbf{1}$ was observed in different populations of A. verticillata, ranging from 0.024 (Natal, Brazil) to $2.480 \mathrm{mg} \mathrm{g}^{-1}$ (Arraial do Cabo, Brazil). Intermediate values of $0.201 \mathrm{mg} \mathrm{g}^{-1}$ were observed for A. verticillata specimens collected at Coon Island (Florida, USA), $0.045 \mathrm{mg} \mathrm{g}^{-1}$ at Little Jim (Florida, USA), $0.316 \mathrm{mg} \mathrm{g}^{-1}$ at Peacock's (Florida, USA) and $0.571 \mathrm{mg} \mathrm{g}^{-1}$ in individuals collected at La Spezia (Italy).

Along with 2,5,6-tribromo- $N$-methylgramine (1), a structurally related new alkaloid was isolated from A. verticillata and identified as 2,6-dibromo- $N$ methylgramine (2). Analysis of $\mathbf{2}$ by high-resolution mass spectrometry showed a $[\mathrm{M}+\mathrm{H}]^{+}$ion at $m / z 344.99585$ together with two additional peaks at $\mathrm{m} / \mathrm{z} 346.95670$ and 348.95470 in 1:2:1 isotopic ratio distribution, indicating the formula $\mathrm{C}_{12} \mathrm{H}_{14} \mathrm{Br}_{2} \mathrm{~N}_{2}$ with one bromine atom less than compound $\mathbf{1}$. Analysis by ${ }^{1} \mathrm{H},{ }^{13} \mathrm{C}$, correlation spectroscopy (COSY), heteronuclear single quantum coherence spectroscopy (HSQC) and heteronuclear multiple bond coherence spectroscopy (HMBC) of $\mathbf{2}$ indicated its close structural relationship to $\mathbf{1}$. The position of the bromine atom in the benzene ring was established as follows. The methylene hydrogens at $\delta 3.48\left(\mathrm{CH}_{2}-8\right)$ showed an HMBC correlation with the signal at $\delta 125.2$, assigned to C-3a. The ${ }^{1} \mathrm{H}$ signal at $\delta 7.46(\mathrm{~d}, 8.8 \mathrm{~Hz}, \mathrm{H}-4)$ showed a correlation with C-3a and a vicinal coupling with $\mathrm{H}-5$ at $\delta 7.28$ (dd, 8.7 and $1.9 \mathrm{~Hz}$ ). Therefore, the bromine atom was positioned at C-6 $(\delta$ 117.1). Although H-7 $(\delta 7.76, \mathrm{~d}, 1.5)$ did not show any correlation in the $\mathrm{HMBC}$ spectrum of 2, the indole $N$-methyl group $\left(\delta 3.73, \mathrm{~s}, \mathrm{H}_{3} \mathrm{C}-10\right)$ showed $\mathrm{HMBC}$ correlations to carbons at $\delta 135.7(\mathrm{C}-7 \mathrm{a})$ and $\delta 116.5$ (C-2), corroborating the structure of the compound $\mathbf{2}$ as 2,6-dibromo- $N$-methylgramine (Table 2). The new natural product 2 was found only in specimens of A. verticillata collected at two Brazilian locations, Cabo Frio (RJ) and Porto Belo (SC), as well as from two sites in Florida, Little Jim and Coon Island (Table 1).

Among the field fish feeding assays performed at Rio de Janeiro, only the extract from specimens of A. verticillata

Table 2. ${ }^{1} \mathrm{H}(600 \mathrm{MHz})$ and ${ }^{13} \mathrm{C} \mathrm{NMR}(150 \mathrm{MHz})$ data for 2,6-dibromo$N$-methylgramine (2) in DMSO- $d_{6}[\delta$, multiplicity $(J$ in $\mathrm{Hz})]$

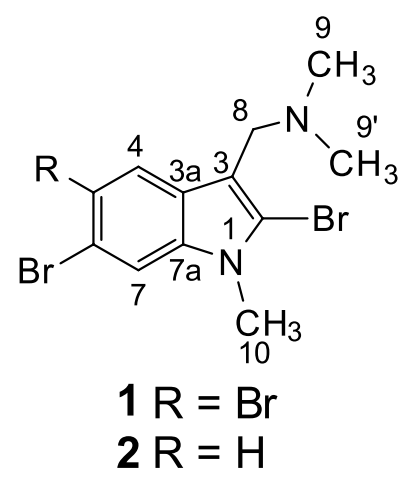

\begin{tabular}{lcc}
\hline Position & ${ }^{13} \mathrm{C}(\delta)$ & ${ }^{1} \mathrm{H}(\delta, J$ in $\mathrm{Hz})$ \\
\hline 2 & 116.5 & \\
3 & 111.5 & \\
$3 \mathrm{a}$ & 125.2 & $7.46(\mathrm{~d}, 8.8)$ \\
4 & 112.3 & $7.28(\mathrm{dd}, 8.7,1.9)$ \\
5 & 124.5 & \\
6 & 117.1 & $7.76(\mathrm{~d}, 1.5)$ \\
7 & 121.2 & \\
$7 \mathrm{a}$ & 135.7 & $3.48(\mathrm{~s})$ \\
8 & 54.1 & $2.13(\mathrm{~s})$ \\
9,9, & 45.2 & $3.73(\mathrm{~s})$ \\
10 & 31.8 & \\
\hline
\end{tabular}


collected at Cabo Frio significantly inhibited feeding by fishes belonging to Chaetodontidae, Haemulidae, Labridae and Pomacentridae families $(p=0.005, t$-test, Figure 1), as evidence of a sympatric activity. The crude extract of A. verticillata collected at Little Jim, Florida, rather stimulated the feeding by fishes at Rio de Janeiro $(p=0.013, t$-test, Figure 1).

When field assays were carried out in Florida, only the extract from specimens of $A$. verticillata collected at Little Jim was able to inhibit predation by fishes belonging to
Pomacentridae, Haemulidae, Pomacanthidae, Lutjanidae and Sparidae families ( $p=0.033, t$-test, Figure 2), in a sympatric action. None of the other extracts from specimens collected in the Indian River Lagoon, Florida (Peacock's Pocket, Jack Island or Jupiter) significantly affected feeding by fishes.

Chemical ecology investigations of bryozoans have been conducted only for a few species. For example, extracts of Amathia wilsoni and Orthoscuticella ventricosa inhibited feeding by fishes in laboratory trials, ${ }^{10}$ Amathia convulata

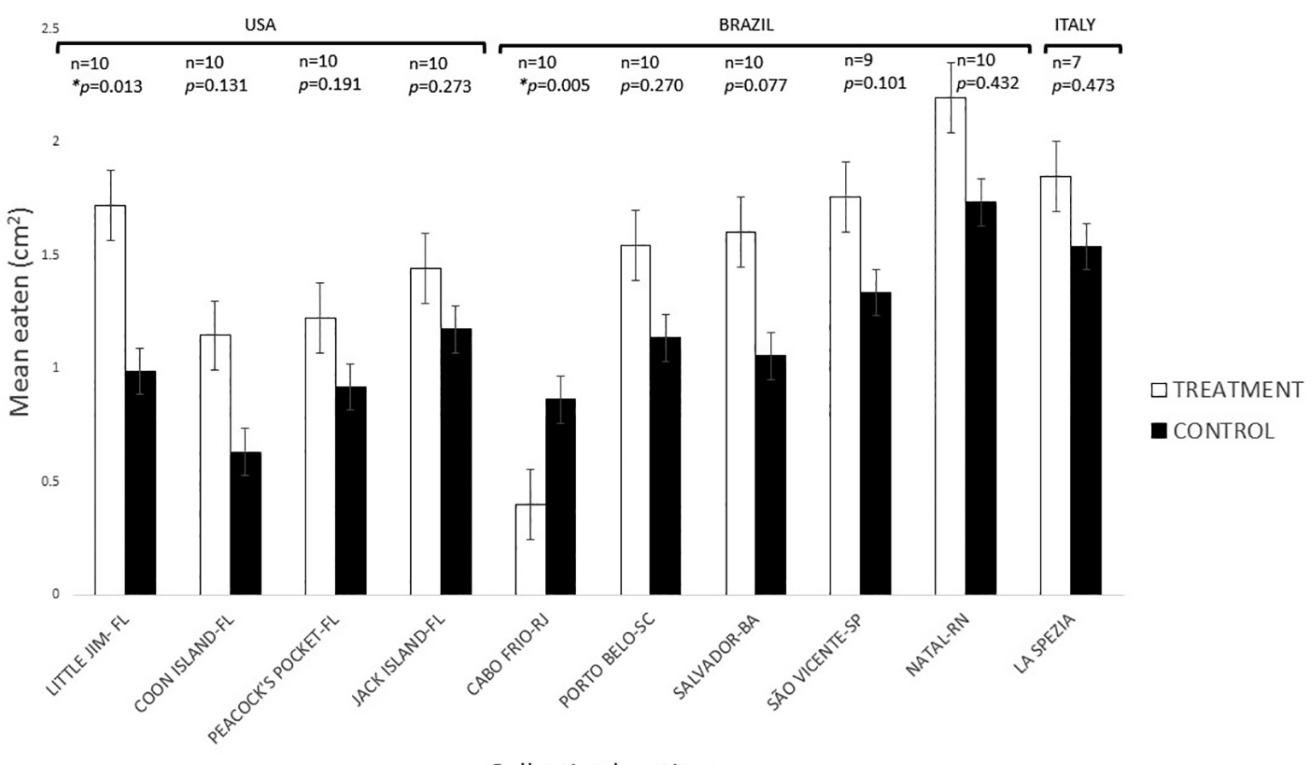

Collection location

Figure 1. Average consumption of artificial foods, treatment (with crude extract of A. verticillata) and control, in the field assays carried out in Rio de Janeiro, Brazil. Vertical bars represent mean area of feeding pieces eaten by fishes. Number of replicates (n) and $p$-values are indicated above the columns. Error bars correspond to \pm 1 standard error.

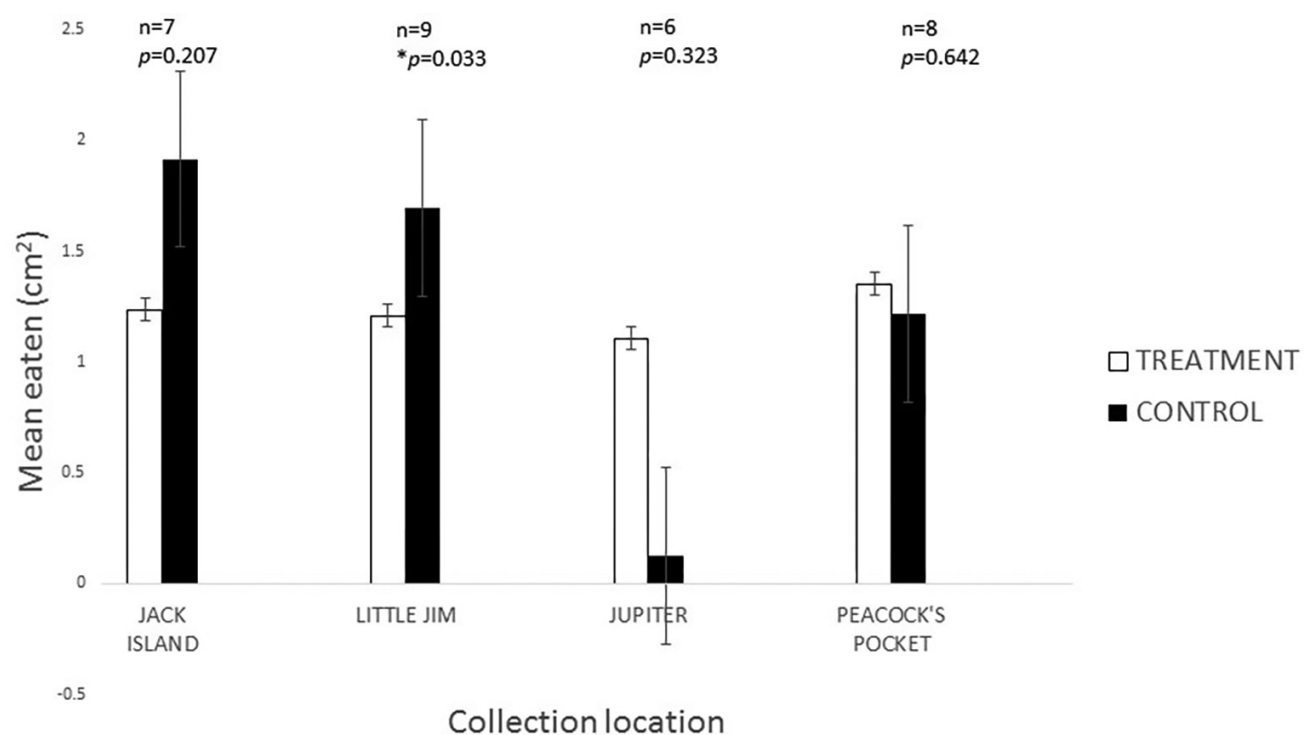

Figure 2. Average consumption of artificial foods, treatment (with crude extract of $A$. verticillata) and control, in the field assays carried out in Jupiter, Florida, United States. Vertical bars represent mean area of feeding pieces eaten by fish. Number of replicates (n) and $p$-values are indicated above the bars. Error bars correspond to \pm 1 standard error. 
inhibited consumption by the pinfish Lagodon rhomboides, ${ }^{31}$ and Alcyonidium flabelliforme, Bostrychopora dentata, Cellaria diversa, Isoschizoporella secunda, and Isosecuriflustra tenuis are defended against the sea star Odontaster validus..$^{32}$ Larvae of Bugula neritina also possess chemicals that confer protection against the fishes Lagodon rhomboides and Monocanthus ciliatus. ${ }^{12}$ Predator-prey interactions between specialist predators, such as nudibranchs, and bryozoans also appear to be chemically mediated. An $N$-methyl analogue of janolusimide tripeptide has been isolated from Bugula flabellata. Janolusimide was previously reported from Janolus cristatus, a nudibranch known to prey on B. flabellata. ${ }^{16}$ Both the bryozoan Bugula dentata and its predator the nudibranch Tambja stegosauriformis yield identical tambjamines. ${ }^{15}$

Extracts from some populations of A. verticillata inhibit predation, but only against sympatric fishes. Such feeding inhibitory activity was observed for A. verticillata specimens collected at Cabo Frio, Rio de Janeiro, in assays carried out in Rio de Janeiro, and from Little Jim (FL, USA) specimens in assays performed in Florida. In allopatric approaches, the predator has had no prior exposure to defensive chemicals of the prey over evolutionary time and would not have acquired resistance or learned aversion. ${ }^{33}$ On the other hand, the sympatric approach evaluates whether chemical deterrents are effective against ecologically relevant predators. ${ }^{34}$ The dual approach is best if possible, ${ }^{35}$ and could test the magnitude of the defensive action of a particular extract or metabolite from a particular species. However, all populations of A. verticillata possess 2,5,6-tribromo- $N$-methylgramine (1) as the major metabolite. In this study, there was no consistent evidence of chemical defenses against fish consumers. Only 2 of 10 extracts tested showed evidence of chemical defense, one other was significantly attractant, and most tended to have more of the treatment eaten than the control food.

For the two extracts that were deterrent, A. verticillata collected at Cabo Frio (RJ, Brazil) contained the second highest concentration of 2,5,6-tribromo- $N$-methylgramine $\left(0.683 \mathrm{mg} \mathrm{g}^{-1}\right)$, while the Little Jim (FL, USA) specimens contained the second lowest concentration $\left(0.045 \mathrm{mg} \mathrm{g}^{-1}\right)$, suggesting that defensive activity of $A$. verticillata against fishes may not be due to this metabolite alone. The defensive activity of extracts may be due to other metabolites, ${ }^{36}$ additive $^{37}$ or synergistic effects produced by several chemicals or by chemical and skeletal/structural elements together. ${ }^{38}$ The new 2,6-dibromo- $N$-methylgramine (2) was found in the populations of A. verticillata from Cabo Frio and Little Jim, but also in two other populations (Porto Belo, SC, Brazil and Coon Island, FL, USA) that did not inhibit feeding by fishes. Thus, it was not possible to make any inference of involvement of this compound in the chemical defenses of A. verticillata. Since this bryozoan is an exotic species, adaptation to a new region should be a key reason to understand the evolution of defensive chemistry and should be explored in future studies.

A. verticillata is an exotic species widely distributed in temperate and tropical waters of the western Atlantic and the Caribbean, ${ }^{23}$ in the Indo-Pacific ${ }^{39}$ and also in the Mediterranean. ${ }^{40}$ Although it has been suggested as native to the Mediterranean ${ }^{41}$ and the Caribbean, ${ }^{42}$ its origin remains unknown. This worldwide distribution of A. verticillata is a consequence of its fouling behavior in many places around the world. ${ }^{23,24}$ Defensive chemistry against consumers and competitors has been proposed as an effective strategy for exotic species to colonize new areas in the marine environment, ${ }^{22}$ but was not observed in the present investigation.

There are several, sometimes redundant, hypotheses to explain why exotic species may become invasive. For example, the novel weapons hypothesis predicts that exotic species may have distinct secondary metabolites not found in native ones, which would be toxic to unadapted native species, ${ }^{43}$ and suggesting that novel chemistry can indeed contribute to invasion success. ${ }^{44}$ For example, unique and abundant chemistry of exotic species may be indicative of biological invasion potential. ${ }^{45}$ But a meta-analysis on 100 exotic plant species revealed that native herbivores suppressed exotic plants, or plants are especially susceptible to novel, generalist herbivores that they have not been selected to resist. ${ }^{46}$

Our findings that defensive activity was only observed in two populations of $A$. verticillata clearly do not support the hypothesis that its defensive chemistry against consumers could be useful to facilitate the bryozoan's introduction and establishment in a new area by overcoming consumers. The success of $A$. verticillata in new areas may be due to reasons other than their defensive chemistry against consumers, an aspect of $A$. verticillata biology which is under investigation with results to be reported in due time.

\section{Conclusion}

The present study brings new insights into the chemical ecology of $A$. verticillata and may contribute to a better understanding of the secondary metabolites and defensive potential of this bryozoan species through its geographical distribution. A new compound, 2,6-dibromo$\mathrm{N}$-methylgramine was discovered in several populations of A. verticilllata in addition to its major metabolite 2,5,6-tribromo- $N$-methylgramine. These compounds do not 
appear to deter fish consumers, thus we found no consistent evidence of chemical defense in this broadly distributed invasive bryozoan.

\section{Supplementary Information}

Supplementary information $\left({ }^{1} \mathrm{H},{ }^{13} \mathrm{C}, \mathrm{HSQC}, \mathrm{COSY}\right.$ and HMBC NMR spectra of compound 2) is available free of charge at http://jbcs.sbq.org.br.

\section{Acknowledgments}

The authors thank Dr Sarath Gunasekera and staff from the Smithsonian Marine Station at Fort Pierce for laboratory and field assistance, and Dr Álvaro Migotto, Dr Karin Fehlauer, Dr Leandro Vieira, Karine Nascimento and Bruno Sayão (Centro de Biologia Marinha, Universidade de São Paulo), for the collection and identification of bryozoan specimens along the Brazilian coastline and for the graphical abstract picture of A. verticillata. The authors also thank Chiara Lombardi for the collection of A. verticillata specimens at Italy. We are grateful to Judith Winston for valuable discussions. The study was carried out under SISBIO license 34321-2 in Brazil. Financial support to R. G. S. B. was provided by a BIOprospecTA/BIOTA grant (2013/50228-8). A Smithsonian Link Foundation Graduate Fellowship Award and CAPES (Coordination for the Improvement of Higher Education Personel) supported this research by LHS. This is contribution from the Smithsonian Marine Station at Fort Pierce.

\section{References}

1. Peters, L.; Konig, G. M.; Wright, A. D.; Pukall, R.; Stackebrand, E.; Eberl, L.; Riedel, K.; Appl. Environ. Microbiol. 2003, 69, 3469.

2. Bosch, T. C. G.; McFall-Ngaib, M. J.; Zoology 2011, 114, 185.

3. Hageman, S. J.; Integr. Comp. Biol. 2003, 43, 87.

4. Sharp, J. H.; Winson, M. K.; Porter, J. S.; Nat. Prod. Rep. 2007, $24,659$.

5. Gribble, G. W.; Alkaloids: Chem. Biol. Perspect. 2012, 71, 1.

6. Blunt, J. W.; Copp, B. R.; Keyzers, R. A.; Munro, M. H. G.; Prinsep, M. R.; Nat. Prod. Rep. 2015, 32, 116.

7. Ruan, B. F.; Zhu, H. L.; Curr. Med. Chem. 2012, 19, 2652.

8. Davidson, S. K.; Allen, S. W.; Lim, G. E.; Anderson, C. M.; Haygood, M. G.; Appl. Environ. Microbiol. 2001, 67, 4531.

9. Yao, B.; Prinsep, M. R.; Nicholson, B. K.; Gordon, D. P.; J. Nat. Prod. 2003, 66, 1074.

10. Blackman, A. J.; Walls, J. T. In Studies in Natural Products Chemistry, vol. 17; Rahman, A., ed.; Elsevier: Amsterdam, Netherlands, 1995, p. 73.
11. Walls, J. T.; Ritz, D. A.; Blackman, A. J.; J. Exp. Mar. Biol. Ecol. 1993, 169, 1.

12. Lindquist, N.; Hay, M. E.; Ecol. Monogr. 1996, 66, 431.

13. Carté, B.; Faulkner, D. J.; J. Chem. Ecol. 1986, 12, 795.

14. Waeschenbach, A.; Vieira, L. M.; Reverter-Gil, O.; SoutoDerungs, J.; Nascimento, K. B.; Fehlauer-Ale, K. K.; Zool. Scr. 2015, 44, 667.

15. Pereira, F. R.; Berlinck, R. G. S.; Rodrigues Filho, E.; Veloso, K.; Ferreira, A. G.; Padula, V.; Quim. Nova 2012, 35, 2194.

16. Wang, J.; Prinsep, M. R.; Gordon, D. P.; Page, M. J.; Copp, B. R.; J. Nat. Prod. 2014, 78, 530.

17. Sodano, G.; Spinella, A.; Tetrahedron Lett. 1986, 27, 2505.

18. Kon-ya, K.; Shimidzu, N.; Adachi, K.; Miki, W.; Fish. Sci. 1994, 60, 773 .

19. Sato, A.; Fenical, W.; Tetrahedron Lett. 1983, 24, 481.

20. Ortega, M. J.; Zubia, E.; Salva, J.; J. Nat. Prod. 1993, 56, 633.

21. Boudouresque, C. F.; Lemme, R.; Mari, X.; Meinesz, A.; Aquat. Bot. 1996, 53, 245.

22. Lages, B. G.; Fleury, B. G.; Ferreira, C. E. L.; Pereira, R. C.; J. Exp. Mar. Biol. Ecol. 2006, 328, 127.

23. Amat, J. N.; Tempera, F.; Mar. Poll. Bull. 2009, 58, 761.

24. Marchini, A.; Ferrario, J.; Minchin, D.; Sci. Mar. 2015, 79, 355.

25. Cranfield, H. J.; Gordon, D. P.; Willan, R. C.; Marshall, B. A.; Battershill, C. N.; Francis, M. P.; Nelson, W. A.; Glasby, C. J.; Read, G. B.; NIWA Technical Report 1998, 34, 1.

26. Vieira, L. M.; Migotto, A. E.; Winston, J. E.; Zootaxa 2008 , $1810,1$.

27. Wirtz, P.; Canning-Clode, J.; Aquat. Invas. 2009, 4, 669.

28. Knapp, I. S.; Godwin, L. S.; Smith, J. E.; Williams, C. J.; Bell, J. J.; Mar. Biodiv. Rec. 2011, 4, 1.

29. Nagy, L.; Early Detection and Rapid Response; Managers Tool Kit, 2006. Available at http://www.invasivespeciesinfo.gov/ toolkit/detelk.shtml, accessed in September 2016.

30. Lopanik, N. B.; Target, N. M.; Lindquist, N.; Mar. Ecol.: Prog. Ser. 2006, 327, 183.

31. Montanari, A. M.; Fenical, W.; Lindquist, N.; Lee, A. Y.; Clardy, J.; Tetrahedron 1996, 52, 5371.

32. Taboada, S.; Núñez-Pons, L.; Avila, C.; Polar Biol. 2012, 36, 13.

33. McClintock, J. B.; Vernon, J. D.; Mar. Biol. 1990, 105, 491.

34. Hay, M. E.; J. Exp. Mar. Biol. Ecol. 1996, 200, 103.

35. McClintock, J. B.; Baker, B. J.; Steinberg, D. K. In Marine Chemical Ecology; McClintock, J. B.; Baker, B. J., eds.; CRC Marine Science Series: Boca Raton, USA, 2001, ch. 5.

36. Pereira, R. C.; Soares, A. R.; Teixeira, V. L.; Da Gama, B. A. P.; Villaça, R.; Bot. Mar. 2004, 47, 202.

37. Koh, L. L.; Goh, N. K. C.; Chou, L. M.; Tan, Y. W.; J. Exp. Mar. Biol. Ecol. 2000, 251, 103.

38. Ribeiro, S. M.; Cassiano, K. M.; Cavalcanti, D. N.; Teixeira, V. L.; Pereira, R. C.; J. Sea Res. 2012, 68, 57. 
39. Antit, M.; Gofas, S.; Salas, C.; Azzouna, A.; Mediterr. Mar. Sci. 2011, 12, 53 .

40. Corriero, G.; Longo, C.; Mercurio, M.; Marchini, A.; Occhipinti-Ambrogi, A.; Ital. J. Zool. 2007, 74, 21.

41. Carlton, J. T.; Eldredge, L. G.; Bishop Mus. Bull. Cult. Environ. Stud. 2009, 4, 1.

42. Canning-Clode, J.; Fofonoff, P.; McCann, L.; Carlton, J. T.; Ruiz, G. M.; Aquat. Invas. 2013, 8, 261.

43. Callaway, R. M.; Aschehoug, E. T.; Science 2000, 290, 2075.

44. Cappuccino, N.; Arnason, J. T.; Biol. Lett. 2006, 2, 189.
45. Macel, M.; de Vos, R. C. H.; Jansen, J. J.; van der Putten, W. H.; van Dam, N. M.; Ecol. Evol. 2014, 4, 2777.

46. Parker, J. D.; Burkepile, D. E.; Hay, M. E.; Science 2006, 311, 1459.

Submitted: May 27, 2016 Published online: September 15, 2016

FAPESP has sponsored the publication of this article. 